\title{
A Comparative Analysis of Entrepreneurial Growth Expectations Between India and Ethiopia
}

\author{
Dr. Shashi Kant \\ Assistant Professor, CBE, Bule Hora University, Ethiopia
}

\begin{abstract}
As a strategy of economic growth entrepreneurship can be successful only if it is duly imparted and conscientiously induced. The peculiarity of adequate literature that assesses difference between growth expectation of entrepreneurs in Ethiopia and India motivated the researcher to conduct this comparative study. Hence, this research aimed at compares the growth expectation of entrepreneurs of these two developing economies. Research followed a descriptive research design to successful achieve the objectives of the research. Research utilized the Global Entrepreneurship Monitor (GEM) index of adult population dataset collected with the help of adult population survey (APS) of entrepreneurial growth expectations and various statistical tools were used to analyze the GEM data. The analysis of the data was carried out using SPSS version 20.The major finding of the study reveals that Ethiopian entrepreneurs has more perceived opportunities as compared to India and Ethiopia population who are either a nascent entrepreneur or owner-manager of a new business shows comparatively stronger situation than India. There is commonality between growth expectations of entrepreneurs in these countries. The study recommends and underscores the importance of determinants that facilitate cooperation and collaboration among Indian and Ethiopian entrepreneurs. Stakeholders, particularly the government, need to give undivided attention and support to institutions bestowed with the task of facilitating collaboration among the entrepreneurs.
\end{abstract}

Keywords: Growth Expectation, Global Entrepreneurship Monitor, National Culture.

DOI: $10.7176 / \mathrm{EJBM} / 12-24-04$

Publication date:August $31^{\text {st }} 2020$

\section{Introduction}

According to neoclassical economist Solow and Swan (1956) determining the driver of economic growth and entrepreneurial growth for a nation is the challenging task. While Romer (1986) in his endogenous growth theory focus on one more factor that is; knowledge. But Acs and Audretsch $(2005,2012)$ propounded that entrepreneurship as a factor of third parties enterprise has more substantial effect on a nation growth as compare to capital and labor. Global sub-prime crisis that intensify the problem of unemployment among youth brought the policy makers attention towards the solution side that is entrepreneurship, which is considered an engine for economic growth and level of potential entrepreneurship is based on entrepreneurial growth expectations. Because it paved the way towards the new jobs creation, new employment opportunities, the materialization of new innovations, but also to the prompt the competition and competitiveness (Wennekers, 1999). Carree, M.A.; Thurik (2003) Audretsch, D.B.; Keilbach (2004) in their study concluded that entrepreneurial expectations serves as a means for introducing innovations, knowledge spillovers, increasing competition, and increasing the variety of businesses.

However, empirical studies by Stam and Van Stel (2009) also identify the role of macro environment like socio-cultural environment 1 and policy framework in development of entrepreneurial intention. Also Ovidiu Stoica, Angela Romanm and Valentina Diana Rusu (2020) in their comparative analysis investigated that opportunity-driven entrepreneurship and early-stage entrepreneurship would be key factors in stimulating economic growth across the sample of European countries. Their estimations also show that opportunity-driven entrepreneurship would have a greater impact in transition countries, while necessity-driven entrepreneurship would have a stronger influence in the innovation-driven countries. Nascent entrepreneurship as dynamics of entrepreneurship postulated a heterogeneity across different nations. Studies that are based on Global Entrepreneurship Monitor (GEM) depicts clearly the variations among entrepreneurial growth expectations between developed and developing countries and also with in itself among developing countries (Reynolds, Bygrave, Autio, Cox and Hay, 2002; Acs, Arenius, Hay and Minniti, 2005).

Entrepreneurship based comparison between two countries is a tricky task. Moreover, starting a new venture in developing nations differentiated on the bases of entrepreneurial growth expectations. Often orientation towards international business and new product development considered as the bases of entrepreneurial growth expectations (Herrington and Kelllley,2012).

In the present paper research we will distinguish between entrepreneurship growth expectations between India and Ethiopia on bases of different parameters. These parameters are orientation towards international business and new product development (Reynolds and White 1997). Present paper also addresses the elected framework of entrepreneurship determinants that is engagement levels (Audretsch, Thurik, Verheul and Wennekers ,2002). The 
purpose of this framework is to understand and analyze what determines entrepreneurship.

\section{LIERATURE REVIEW}

Entrepreneurial growth expectation has been defined as the consideration of future expansion and the aspiration to develop one's own venture (Herrington \& Kelley, 2012). Alemayehu, Vuuren \& Groenewald (2017) concluded that entrepreneur's growth expectation is determined by their orientation towards international business and new product development. They also designated that entrepreneurship quality (creation of business is driven by opportunity or lack of opportunity) also have an impact on entrepreneurial growth expectation. Karadeniz and Özcam (2010) in their article claim that demographic factors such as education level, gender, and family income and level of motivation and businesses size of early stage entrepreneurs have significant impact on entrepreneurial growth expectation.

Similarly, Beier and Wagner (2017) assert that personal traits and intended strategies play a crucial role in the growth expectation of Total early-stage Entrepreneurial Activity.

Moreover, one more factor "networking based on information" as identified by Daskalopoulou and Petrou (2010) manifested a decisive part for the future of well informed entrepreneurs helping them in sensing the opportunity. Delmar; Wiklund (2008) and Stenholm (2011) explored "motivation to grow" as the other aspects of growth expectation. Even in the resource less environment motivation to grow forces the entrepreneur to nurture his venture. (Alemayehu, et al., 2017).Attractive market opportunities motivated a entrepreneur better than push factors such as unemployment or underemployment for growth (Alemayehu, et al., 2017) and self dependency and survival need in uncertain environment act as the higest motivation for grow in early stage developing economies (Herrington \& Kelley, 2012). Research findings of many researches find gender correlation with entrepreneurial growth expectations. Cliff (1998) found out the gender especially masculinity as the factor that effect entrepreneurial growth expectation but according to Morgan and Siak (2016) fear of failure is the main factor.

In collective terms after investigation of findings of above empirical studies it is postulated that Entrepreneurial intentions, Perceived opportunities and Entrepreneurial Employee Activity responsible for entrepreneurial growth expectation. (Herrington \& Kelley, 2012; Cheraghi, et al., 2014; Alemayehu, et al., 2017).

\subsection{Empirical Studies on India and Ethiopia}

The indicating results from developing economies illustrate a similar pattern. Like in case of study conducted by Das (1995), related with the Indian hardware market, found a significant negative correlation between growth of enterprise and Total early-stage Entrepreneurial Activity (TEA); similarly in a research of five south African economies McPherson (1996) founded a negative correlation between enterprise growth and Total early-stage Entrepreneurial Activity (TEA); Goedhuys and Sleuwaegen (2000) and Sleuwaegen, L. and Goedhuys, M. (2002), respectively examining 141 and 129 enterprises engaged in manufacturing segment in Côte d'Ivoire, also found a negative correlations between enterprise growth and Total early-stage Entrepreneurial Activity (TEA. Over the period 1996-2003, running GEM panel, conducted a census-based study on Ethiopian manufacturing enterprises shows a similar result. Bigsten and Gebreeyesus (2007) study also showed the negative correlation between Total early-stage Entrepreneurial Activity (TEA) and enterprises employment growth. Mengistae (2001) during analyzing a randomly-selected sample of 296 Ethiopian SMEs, finds that the indigenous minority group owned enterprises of the Gurage perform superior in the Ethiopia; in particular, new ventures start larger and then grow faster. More recently, Goedhuys and Sleuwaegen (2010) show that the Asian dummy (Indian, Middle Eastern or other Asian origin) turns out to be positive and significant in affecting ventures growth in Sub-Saharan Africa.

\section{Research Methodology}

Since the comparative analysis of entrepreneurial growth expectations is totally based on secondary GEM data, that exploited the adult population dataset of GEM for the year 2013 in which Ethiopia and India are a part. Besides, in terms of approach, the research has used a descriptive research design. Ethiopia and India were a part of GEM 2013 report and the institution (GEM) elicited a huge data from more than 3000 women and men entrepreneurs. The preliminary assessment conducted by the researcher on the data quality and reliability indicated that it is a good source if used properly. Therefore, driven by the view of making use of this data and associated benefits, the required data for this study was drawn from this source. To support findings, published articles and reports were also used. 


\section{DATA ANALYSIS}

Table1: Comparison of Entrepreneurial Growth Expectations between Ethiopia and India. Indicator

\begin{tabular}{|c|c|c|c|}
\hline \multirow[t]{2}{*}{ maicator } & \multicolumn{2}{|c|}{ suo sanaran region } & \multirow{2}{*}{$\begin{array}{l}\text { Region } \\
\text { India }\end{array}$} \\
\hline & $\begin{array}{l}\text { Growth } \\
\text { Expectation }\end{array}$ & Ethiopia & \\
\hline $\begin{array}{l}\text { Percentage of } 18-64 \text { population who see good } \\
\text { opportunities to start a firm in the area where they } \\
\text { live }\end{array}$ & $\begin{array}{l}\text { Perceived } \\
\text { opportunities }\end{array}$ & 64.89 & 41.43 \\
\hline $\begin{array}{l}\text { Percentage of } 18-64 \text { population who believe they } \\
\text { have the required skills and knowledge to start a } \\
\text { business }\end{array}$ & $\begin{array}{l}\text { Perceived } \\
\text { capabilities }\end{array}$ & 69.1 & 55.78 \\
\hline $\begin{array}{l}\text { Percentage of } 18-64 \text { population perceiving good } \\
\text { opportunities to start a business who indicate that fear } \\
\text { of failure would prevent them from setting up a } \\
\text { business }\end{array}$ & $\begin{array}{l}\text { Fear of failure } \\
\text { rate }\end{array}$ & 32.66 & 38.91 \\
\hline $\begin{array}{l}\text { Percentage of } 18-64 \text { population (individuals involved } \\
\text { in any stage of entrepreneurial activity excluded) } \\
\text { who are latent entrepreneurs and who intend to start } \\
\text { a business within three years }\end{array}$ & $\begin{array}{l}\text { Entrepreneurial } \\
\text { intentions }\end{array}$ & 23.84 & 22.79 \\
\hline $\begin{array}{l}\text { Percentage of } 18-64 \text { population who are either a } \\
\text { nascent entrepreneur or owner-manager of a new } \\
\text { business }\end{array}$ & $\begin{array}{l}\text { Total early- } \\
\text { stage } \\
\text { Entrepreneurial } \\
\text { Activity (TEA) }\end{array}$ & 14.73 & 9.88 \\
\hline $\begin{array}{l}\text { Percentage of 18-64 population who are currently an } \\
\text { owner-manager of an established business, i.e., } \\
\text { owning and managing a running business that has } \\
\text { paid salaries, wages, or any other payments to the } \\
\text { owners for more than } 42 \text { months }\end{array}$ & $\begin{array}{l}\text { Established } \\
\text { Business } \\
\text { Ownership }\end{array}$ & 10.2 & 10.66 \\
\hline $\begin{array}{l}\text { Rate of involvement of employees in entrepreneurial } \\
\text { activities, such as developing or launching new } \\
\text { goods or services, or setting up a new business unit, } \\
\text { a new establishment or subsidiary }\end{array}$ & $\begin{array}{l}\text { Entrepreneurial } \\
\text { Employee } \\
\text { Activity }\end{array}$ & 0.57 & 0.93 \\
\hline $\begin{array}{l}\text { Percentage of those involved in TEA that are } \\
\text { improvement-driven opportunity motivated, divided } \\
\text { by the percentage of TEA that is necessity-motivated }\end{array}$ & $\begin{array}{l}\text { Motivational } \\
\text { Index }\end{array}$ & 3.4 & 0.93 \\
\hline $\begin{array}{l}\text { Percentage of female } 18-64 \text { population who are either } \\
\text { a nascent entrepreneur or owner-manager of a new } \\
\text { business, divided by the equivalent percentage for } \\
\text { their male counterparts }\end{array}$ & $\begin{array}{l}\text { Female/Male } \\
\text { TEA }\end{array}$ & 0.78 & 1.0 \\
\hline $\begin{array}{l}\text { Percentage of those involved in TEA who indicate } \\
\text { that their product or service is new to at least some } \\
\text { customers AND that few/no businesses offer the } \\
\text { same product }\end{array}$ & Innovation & 13.6 & 20.94 \\
\hline
\end{tabular}

SOURCE: Extracted from GEM DATA, 2013

From the table 1 it is considered that a considerable portion $(64.89 \%)$ in Ethiopia more perceived opportunities as compared to India $(41.43 \%$ ) postulates a better scenario. Similarly 69.1 percentage of Ethiopian population who believe they have the required skills and knowledge to start a business have better perceived capabilities than India (55.78\%). $23.84 \%$ population of Ethiopia (individuals involved in any stage of entrepreneurial activity excluded) who are latent entrepreneurs and who intend to start a business within three years shows a remarkable better position in Entrepreneurial intentions than India (22.79\%). In case of Total earlystage Entrepreneurial Activity (TEA), $14.73 \%$ of 18-64 age groups Ethiopia population who are either a nascent entrepreneur or owner-manager of a new business shows comparatively stronger situation than India (9.88\%). But in case of established Business Ownership (10.2\%), Entrepreneurial Employee Activity (0.57\%), Female/Male TEA $(0.78 \%)$ and specially Innovation (13.6\%); Ethiopia slightly behind the Indian growth expectation parameter. These numbers imply that majority of entrepreneurs in both countries are better aligned when it comes to entrepreneurial growth expectations. The lower level of Female/Male TEA in entrepreneurial growth expectations could also be taken as the reflection of patriarchal societal belief and norms that has been constraining women 
from seeking personal growth and economic empowerment. Perhaps it is possible to say that majority of them expect to improve their existing position and size in future.

\section{DESCRIPTIVE FINDINGS WITH RESPECT TO EACH STUDY VARIABLE:}

In general, perceived capabilities are higher than perceived opportunities, but they decline along the economic development level-Similarly this pattern is manifested in table 1 in case of India both perceived opportunities (41.43\%) and perceived capabilities (55.78\%) are lower than Ethiopia (64.89\% and 69.1\%) respectively . This pattern shows a long-term economic stability. The same holds for Bosnia and Herzegovina, a non-EU country (19.6\% vs. 47.3\%). High level of perceived opportunities indicates institutions, like professional infrastructure institutions, education sector are more functional in Ethiopia which can help in building the individuals' capacity of recognizing opportunities. Both economies present high social values towards entrepreneurship and high measures of perceived opportunities (regarding the next six months to start a business in the area where their citizens live) and perceived capabilities (the required skills and knowledge to start a business). It means that in both economies entrepreneurship framework conditions are needed in order to support such individual preferences. 5.1 Fear of failure can be a strong inhibitor for seizing opportunities and transforming entrepreneurial intentions into entrepreneurial activity. The high fear of failure (measured among the group with perceived opportunities) was expressed by respondents in Indian economy (38.91\%) than Ethiopia (32.66\%). Generally in the most high stage developing countries, the fear of failure is higher than in factor-driven and. This shows India movement towards efficiency-driven economy from factor driven economy.

5.2 Entrepreneurial intentions are the highest among factor driven economies and the lowest among innovationdriven economies, which confirm the already known pattern that starting an own business is dominant where other options to provide income for living are limited. At the same time, it is obvious that the existence of social values towards entrepreneurship and the quality of the entrepreneurship framework conditions provide support or hindering factors in building entrepreneurial intentions. On the level of individual economies, this is observed interesting in Ethiopian case: there is a high share of respondents with perceived opportunities $(64.89 \%)$ and perceived capabilities (69.1\%), and a low level of fear of failure $(32.66 \%$ ) but that led to very low $23.84 \%$ of respondents with entrepreneurial intentions. Same was seen in case of India such an entrepreneurial activity can take a wide variety of forms, from self-employment in less demanding ventures regarding skills and other resources to knowledge-based ventures.

5.3 Total early-stage entrepreneurial activity (TEA) correlates strongly with capabilities (skills): In order to show interlinked components needed for building entrepreneurial growth expectations, measured with help of TEA. Perceived opportunity (E-64.89\%, I-41.43\%) and perceived capability (skills) (E-69.1\%, I-55.78\%) are not having the high association with TEA (only 14.73 in case of Ethiopia and $9.88 \%$ in case of India). But Ethiopia still exceeds than India in TEA. The reason behind low TEA in both economies is fear of failure that influences entrepreneurial activity (TEA) negatively.

5.4 Motivation for starting a business matters: The identification of differences among economies around the world as for social values, individual attributes and TEA can be better understood if the motivational aspect of starting businesses is included. GEM Adult Population Survey shows a very low Motivation Index in case of India (only $0.93 \%$ ) manifested that he/she started the business because there were no better options to obtain resources for living, necessity driven. Reason behind that most of them engaged in family owned business not on innovation based but in case of Ethiopia percentage is much higher than India (3.4\%) that indicates Improvement-driven opportunity entrepreneurs in the economy. These are those who either started the business because they want to earn more money or to be more independent. TEA also supports present motivation differences in early-stage entrepreneurial growth expectations between two economies.

5.5 Established business ownership: Established businesses are the core of the economic canvas of any country. The balanced dynamics of entering total early stage entrepreneurial activity (TEA) and successful transition toward established businesses should be one of the key concerns of any government and other stakeholders responsible for the well-being of their citizens. In order to provide a stable economic structure, the rate of early-stage entrepreneurial activity should always be higher than the rate of established business ownership (because of the discontinuance rate). Through Table1 when researcher compare TEA rates and established business ownership rates, Ethiopia follow the above general pattern i.e TEA is more than established business ownership $(14.73 \%>$ $10.2 \%$ ) but India scenario is totally different (TEA 9.88\% < EEA $10.66 \%$ ). In India in-spite of low TEA establishment i.e venture conversion rate is high, shows a higher dynamics.

Also in India rate of early-stage entrepreneurial activity (TEA) of $9.88 \%$ is very close to the rate of established business ownership rate of $10.66 \%$. This dynamics can be explained also by the presence of a more efficient entrepreneurship ecosystem (education, $R \& D$ transfer, access to finance, friendly regulatory framework) supporting new entrants in business activity.

5.6 Innovative orientation: GEM looks at innovative orientation of early-stage entrepreneurs through two lenses (product/market): how much an entrepreneur's product/service is new to all or some customers and if few or no 
other businesses offer the same product/service. This measure of innovative orientation is quite a contextdependent measure, because despite globalization, internal market in many economies can recognize some products/services as new one, which already exists on some other markets. Table 1 presents the percentage of early-stage entrepreneurs (TEA) with innovative orientations, measured by:

- The percentage of TEA that declare to have a product/ service which is new for all or some of their customers.

- The percentage of TEA that declare to be new on the market with few or not other businesses offering the same product/ service.

Indian economy is more innovation-oriented than Ethiopia on both criteria, because they enjoy own big indigenous markets, with higher purchasing power, less orientation to new markets due to their own huge markets. Ethiopia is low in both measures but he trying to develop both aspects of innovation capacity — with very high share of early-stage entrepreneurs $(14.73 \%$ as compare to India-9. Reason behind is that Ethiopian entrepreneurs have a product/ service which is new to all or some of their customers, and at the same time they sell on the market where they have only few competitors.

5.7 Entrepreneurial employee activities: The broadest and best-known definition that "entrepreneurship is the process by which individuals pursue opportunities without regard to the resources they currently control" (Gartner and Baker, 2010) is the basis to look for entrepreneurial behavior everywhere. Such definition bridges usual division between "independent entrepreneurship" and "entrepreneurship within and existing organization".

Since its inception, GEM focuses on "independent entrepreneurship" from nascent to start-up phase of business venture. In 2011, the first survey of entrepreneurial activity of employees confirmed that besides early-stage entrepreneurial activity, there is also entrepreneurial activity performed by proactive, innovative and responsible employees (Bosma et al., 2013). GEM highlighted the entrepreneurial employee activity as a situation in which employees develop new products/ services, or set up a new business entity, but not-for instance-work on optimizing internal operations of a firm. The measure of entrepreneurial employee activity (EEA) is lowest in factor-driven Ethiopia and India economies. Both economies have the very low incidence of entrepreneurial employee activity, which confirms the presence of less entrepreneurial culture (proactive, innovative) in their business sectors.

\section{CONCLUSION}

Present study is important for policymakers of both of developing economies because it highlights the importance of entrepreneurship growth expectations of entrepreneurs in Ethiopia and India. An increased share of entrepreneurs motivated by necessity in the economy can lead to long-term effects on economic growth and on business performance. Also existence of social values towards entrepreneurship and the quality of the entrepreneurship framework conditions provide support or hindering factors in building entrepreneurial intentions. Implicitly, decision makers should issue policies to stimulate the business environment and create business opportunities, stimulating the multiplication of entrepreneurs motivated by opportunity generating positive effects on the economy. Additionally, sustained economic growth has positive long-term effects on businesses. Thus, a high quality of the entrepreneurial growth expectations, at present, generates positive effects on the economic growth, and subsequently determines an improvement on the business environment. The results of our study help policy makers and future researchers become aware of implications entrepreneurial growth expectations for measurable entrepreneurship development, and a participatory mechanism to review implementation at the national, regional, and global levels.

\section{REFERENCE}

$>$ Acs, Z.J., P. Arenius, M. Hay and M. Minniti, 2005, Global Entrepreneurship Monitor: 2004 Executive Report, Babson Park, MA: Babson College and London: London Business School.

$>$ Acs, Z.J.; Audretsch, D.B.; Braunerhjelm, P.; Carlsson, B. Growth and Entrepreneurship: An Empirical Assessment; No. 5409; CEPR Discussion Paper; Centre for Economic Policy Research: London, UK, 2005; Available online: https://ssrn.com/abstract=893068 (accessed on 20 march 2020).

$>$ Acs, Z.J.; Audretsch, D.B.; Braunerhjelm, P.; Carlsson, B. Growth and entrepreneurship. Small Bus. Econ. 2012, 39, 289-300.

$>$ Alemayehu, B. Z. \& Vuuren, J. V., 2017. Munificence contingent small business growth model (special emphasis to African SMEs' context). Journal of Small Business \& Entrepreneurship, 29(4), pp. 251-269.

$>$ Alemayehu, B. Z., Vuuren, J. v. \& Groenewald, D., 2017. Factors Contributing to Growth Orientation of African Entrepreneurs. Dar Es Salaam, International Business Conference .

$>$ Audretsch, D.B., A.R. Thurik, I. Verheul and S. Wennekers, 2002, Entrepreneurship: Determinants and Policy in a European-US Comparison, Dordrecht: Kluwer Academic Publishers.

$>$ Audretsch, D.B.; Keilbach, M. Entrepreneurship capital and economic performance. Reg. Stud. 2004, 38, 949-959.

$>$ Bigsten, A. and Gebreeyesus, M. (2007), The Small, the Young and the Productive: Determinants of 
Manufacturing Enterprise Growth in Ethiopia, Economic Development and Cultural Change, 55, 813-40.

$>$ Bogren, M., Friedrichs, Y. v., Rennemo, Ø.\& Widding, Ø., 2013. Networking women entrepreneurs: fruitful for business growth?. International Journal of Gender and Entrepreneurship, 5(1), pp. 60-77.

$>$ Carree, M.A.; Thurik, A.R. The impact of entrepreneurship on economic growth. In Handbook of Entrepreneurship Research; Acs, Z.J., Audretsch, D.B., Eds.; Kluwer Academic Publishers: Boston, MA, USA, 2003; pp. 437-471.

$>$ Cheraghi, M., Setti, Z. \& Schøtt, T., 2014. Growth-expectations among women entrepreneurs: embedded in networks and culture in Algeria, Morocco, Tunisia and in Belgium and France. Int. J. Entrepreneurship and Small Business, 23(1/2), pp. 191-212.

$>$ Daskalopoulou, I. \& Petrou, A., 2010. Entrepreneurial growth expectations and information flows in networks. Journal of Small Business and Enterprise Development, 17(3), pp. 334-349.

$>$ Dawa, S. \& Namatovu, R., 2015 . Social Networks and Growth of Female-Owned Ventures: A Sub- Saharan African Perspective. Journal of Developmental Entrepreneurship, 20(2), pp. 1550009 - 1-19.

$>$ Deck, M. \& Strom, M., 2002. Model of Co-Development Emerges. Research-Technology Management, 45(3), pp. 47-53.

$>$ Emden, Z., Calantone, R. J. \& Droge, C., 2006. Collaborating for New Product Development: Selecting the Partner with Maximum Potential to Create Value. Journal of Product Innovation Management, Volume 23, p. 330-341.

$>$ GEM, G. E. M., 2012, 2013. Low levels of entrepreneurship, but high hopes: HIGHLIGHTS from the GEM Ethiopia Report, London: Global Entrepreneurship Monitor.

$>$ Goedhuys, M. and Sleuwaegen, L. (2000), Entrepreneurship and Growth of Entrepreneurial Enterprises in Côte d'Ivoire, The Journal of Development Studies, 36, 123-45.

$>$ Goedhuys, M. and Sleuwaegen, L. (2010), High-growth Entrepreneurial Enterprises in Africa: A Quantile Regression Approach, Small Business Economics, 34, 31-51.

$>$ Gundry, L. K. \& Welsch, H. P., 2001. The Ambitious Entrepreneur: High Growth Strategies of Owned Enterprises. Journal of Business Venturing, Volume 16, p. 453-470.

$>$ Herrington, M. \& Kelley, D., 2012. African Entrepreneurship: Sub-Saharan African Regional Report, London: Global Entrepreneurship Monitor

$>$ Mengistae, T. (2001), Indigenous Ethnicity and Entrepreneurial Success in Africa: Some Evidence from Ethiopia, World Bank Policy Research Working Paper 2534, Washington DC, World Bank.

$>$ Mueller, P. Exploiting entrepreneurial opportunities: The impact of entrepreneurship on growth. Small Bus. Econ. 2007, 28, 355-362.

$>$ Ovidiu Stoica , Angela Roman and Valentina Diana Rusu, The Nexus between Entrepreneurship and Economic Growth: A Comparative Analysis on Groups of Countries; Sustainability 2020, 12, 1186; doi:10.3390/su12031186

$>$ Reynolds, P.D. and S.B. White, 1997, The Entrepreneurial Process: Economic Growth, Men, Women and Minorities, Westport, CT and London: Quorum Books.

$>$ Reynolds, P.D., 1997, Who starts new firms? - Preliminary explorations of firms-in-gestation, Small Business Economics 9(5), 449-462.

$>$ Reynolds, P.D., Bygrave, W.D., Autio, E., Cox, L.W. and M. Hay, 2002, Global Entrepreneurship Monitor, 2002 Ex-ecutive Report, Babson College, London Business School and Kauffman Foundation.

$>$ Reynolds, P.D., M. Hay and S.M. Camp, 1999, Global Entrepreneurship Monitor: 1999 Executive Report, Babson College, London Business School and the Kauffman Center for Entrepreneurial Leadership.

$>$ Romer, P.M. Increasing returns and long-run growth. J. Polit. Econ. 1986, 94, 1002-1037.

$>$ Singer, S., Amorós, J. E. \& Arreola, D. M., 2014. Global Entrepreneurship Monitor 2014 Global Report, London: Global Entrepreneurship Monitor.

$>$ Solow, R.M. A contribution to the theory of economic growth. Q. J. Econ. 1956, 70, 65-94.

$>$ Stam, E.; Van Stel, A. Types of Entrepreneurship and Economic Growth; Working Paper Series; UNUWIDER: Maastricht, The Netherlands, 2009; p. 49. Available online: https://collections.unu.edu/eserv/UNU:60/ wp2009-049.pdf (accessed on 20 March 2020).

$>$ Swan, T.W. Economic growth and capital accumulation. Econ. Rec. 1956, 32, 334-361

$>$ Wennekers, S.; Thurik, R. Linking entrepreneurship and economic growth. Small Bus. Econ. 1999, 13, 2756. 